\title{
Akad Perbankan Syariah dan Penerapannya dalam Akta Notaris Menurut Undang-Undang Jabatan Notaris
}

\author{
Pandam Nurwulan \\ Fakultas Hukum Universitas Islam Indonesia \\ Jln. Tamansiswa No. 158 Yogyakarta \\ nnurwulan@gmail.com
}

Received: 14 Mei 2018; Accepted: 26 Oktober 2018; Published: 17 Januari 2019

DOI: 10.20885 /iustum.vol25.iss3.art10

\begin{abstract}
This study examines, first, why the binding guarantee in Shariah banking deed still practice the concept used by conventional banking. Second, how the notary formulates Sharia banking deeds in accordance with Law on Notary, and third, the ideal requirements for a notary in formalizing Sharia banking deeds. The research method used is normative legal research by processing and analyzing data in a qualitative descriptive approach. The results show that, first, the binding guarantee of Sharia banking deeds still uses the concept of conventional banking guarantee because there are no Sharia rules/regulations governing a matter of binding guarantee for Sharia deeds (there is a legal vacuum/recht vacuum). As a result, the practice of guarantee binding procedures for Sharia banking deeds uses mortgage and fiduciary rights as is commonly practiced by conventional banking. Secondly, in formulating Sharia deeds, a notary should follow the Law on Notary without leaving the Sharia principles and mechanism/procedure for making a Notary deed. Third, the notary inaugurating Sharia deeds must be well acquainted with Sharia principles, which are based on the divinity principle in Sharia deeds, making it ideal if the notary who legalizes the Sharia deeds is a Muslim.
\end{abstract}

Keywords : Sharia deed; notary deed; binding guarantee; and law on notary

Abstrak

Penelitian ini mengkaji: pertama, mengapa akad perbankan syariah pengikatan jaminannya masih menggunakan konsep yang digunakan perbankan konvensional? Kedua, bagaimana notaris dalam memformulasikan akta akad syariah yang sesuai dengan Undang-Undang Jabatan Notaris? Ketiga, bagaimana persyaratan ideal bagi notaris yang meresmikan akta-akta akad perbankan syariah? Metode penelitian yang digunakan adalah penelitian hukum normatif dengan pengolahan dan analisis data dengan cara deskriptif kualitatif. Dari penelitian ini dapat disimpulkan: pertama, akad perbankan syariah pengikatan jaminannya masih menggunakan konsep jaminan perbankan konvensional karena belum ada ketentuan/regulasi secara syariah yang mengatur tentang pengikatan jaminan untuk akadakad syariah (ada kekosongan hukum/recht vacuum), dengan demikian di dalam praktek prosedur pengikatan jaminan untuk akta-akta akad syariah memakai hak tanggungan dan fidusia sebagaimana yang lazim digunakan oleh perbankan konvensional. Kedua, Notaris dalam memformulasikan akta akad syariah yang dibuat secara notariil formulasi bentuknya harus sesuai dengan Undang-Undang Jabatan Notaris dengan tanpa meninggalkan prinsip-prinsip syariah serta mekanisme/prosedur pembuatan akta Notaris. Ketiga, Notaris yang meresmikan akta-akta akad syariah harus paham betul terhadap prinsip-prinsip syariah, yang mendasarkan pada asas llahiyah dalam akad syariah. sehingga menjadi ideal jika seorang Notaris yang meresmikan akta-akta akad syariah adalah seorang Muslim.

Kata-kata Kunci : Akad syariah; akta notaris; pengikatan jaminan dan undangundang jabatan notaris 


\section{Pendahuluan}

Pertumbuhan bank syariah di Indonesia saat ini sangat pesat, seiring dengan tumbuhnya pemahaman masyarakat bahwa bunga dan modal yang hasilnya telah ditentukan dimuka adalah merupakan riba yang dilarang oleh syariah Islam. Atas dasar pemahaman seperti ini, maka sejak 1950, telah banyak para cendikiawan muslim dan teoritisi ekonomi Islam yang menghendaki keberadaan bank yang terbebas dari bunga atau riba. ${ }^{1}$

Praktik bisnis yang kini dilaksanakan dan senantiasa bersandar pada kontrak bisnis syariah belum sepenuhnya menerapkan prinsip-prinsip syariah. Hal ini antara lain, terjadi pada kontrak pembiayaan syariah yang diselenggarakan oleh lembaga perbankan syariah. Tidak dipenuhinya prinsip-prinsip syariah dalam kontrak-kontrak pembiayaan pada perbankan syariah ini tentunya harus dilihat secara komprehensif, yakni meliputi pada tahapan pra kontrak (pre-contractual), pelaksanaan kontrak (contractual) dan pasca kontrak (post-contractual). Oleh karenanya, Islam dengan tegas dan jelas mendorong sepenuhnya setiap subyek hukum yang terdiri dari individu maupun badan ketika mengadakan berbagai kontrak (akad) agar hati-hati dan senantiasa memperhatikan rukun dan syarat sahnya akad sebagaimana yang ditentukan dalam hukum Islam. ${ }^{2}$

Hal yang menarik dan senantiasa aktual untuk diperbincangkan, baik dalam tataran teori maupun praktisnya, yaitu problematika aspek jaminan dan lembaga jaminan dalam praktek perbankan syariah di Indonesia, yang konon tidak atau belum berlandaskan pada prinsip-prinsip syariah itu sendiri. Penggunaan lembaga jaminan konvensional seperti hak tanggungan dan fidusia masih menjadi pilihan bagi bank-bank syariah. Syarat adanya jaminan (collateral) dalam pembiayaan syariah yang di-cover dengan menggunakan lembaga jaminan konvensional, kiranya patut dicermati bahkan di kritisi keberadaannya. ${ }^{3}$

1 Sumber : http://pasca.unisba.ac.id/akad-murabahah-dan-implementasinya-pada-syariah-dihubungkandengan-kebolehan-praktek-murabahah-menurut-para-ulama/ diakses pada tanggal 09 Mei 2016 Pukul 10: 15 WIB

${ }^{2}$ Aunur Rohim Faqih, Kontrak Bisnis Syariah Studi Mengenai Penerapan Prinsip-Prinsip Syari'ah dalam Pembiayaan Pada Bank Syariah di Indonesia, Ringkasan Desertasi, Program Doktor (S-3) Ilmu Hukum Universitas Islam Indonesia, 2014, hlm.28.

${ }^{3}$ Noor Hafidah, Hukum Jaminan Syariab; Implementasinya dalam Perbankan Syariah di Indonesia, UII Press, Yogyakarta, 2017, hlm. viii 
Praktik perbankan syariah di Indonesia menunjukan bahwa implementasi lembaga jaminan tidak atau belum berlandaskan pada prinsip-prinsip syariah. Lembaga jaminan konvensional seperti hak tanggungan dan fidusia masih menjadi primadona bagi bank-bank syariah. Syarat harus adanya suatu jaminan (collateral) dalam pembiayaan syariah diimplementasikan dengan begitu sumir; mencaplok secara begitu saja institut jaminan konvensional, padahal sistem ekonomi syariah sejak 14 abad lalu telah mengintrodusir suatu bentuk penjaminan atas transaksi non tunai, yaitu al-rahn. ${ }^{4}$

Akad menjadi sesuatu yang penting dalam setiap transaksi, termasuk akad/transaksi dalam bisnis syariah. Agar suatu perjanjian mendapatkan kekuatan hukum, maka harus tercatat di hadapan Notaris. Karena itu, setiap bisnis termasuk di dalamnya adalah bisnis syariah selalu membutuhkan Notaris sebagai pejabat umum yang membuat akta otentik sesuai dengan tugasnya yang diatur dalam Undang-Undang Republik Indonesia Nomor 30 Tahun 2004 tentang Jabatan Notaris jo Undang-Undang Nomor 2 Tahun 2014 tentang Perubahan Atas UndangUndang Nomor 30 Tahun 2004 tentang Jabatan Notaris.

Perkembangan perbankan syariah di Indonesia berpengaruh pada instrumen lainnya, seperti lembaga notaris yang selama ini terlibat dalam mengeluarkan surat keterangan hukum mengenai akad-akad bisnis syariah. ${ }^{5}$ Agar suatu perjanjian mendapatkan kekuatan hukum, maka harus tercatat di hadapan notaris, karena itu setiap bisnis syariah termasuk di dalamnya adalah bisnis syariah selalu membutuhkan notaris sebagai pejabat yang membuat akta otentik sesuai dengan tugasnya yang diatur dalam Undang-Undang Nomor 2 Tahun $2014 .{ }^{6}$

Notaris oleh negara dilimpahi wewenang untuk melaksanakan sebagian tugas negara di bidang hukum privat, berkenaan dengan pelaksanaan akad-akad syariah, sering diminta untuk mengautentikkan hubungan hukum para pihak. Untuk menjamin kepastian, ketertiban dan perlindungan hukum, dibutuhkan alat bukti tertulis yang bersifat autentik mengenai perbuatan, perjanjian, penetapan dan peristiwa hukum yang dibuat oleh atau di hadapan Notaris.

${ }^{4}$ Ibid., hlm. vii

${ }^{5}$ Ustad Aidil, Mengenal Notaris Syariah, Citra Aditya Bakti, Bandung, 2011, hlm. 40

${ }^{6}$ Ibid., hlm. 85-86 
Bank sebagai lembaga keuangan, memanfaatkan jasa hukum notaris dalam setiap perjanjian bisnis, seperti: akad pembiayan, perjanjian kredit, termasuk perjanjian tambahannya yakni mengenai pengikatan jaminan. Pada umumnya bank-bank konvensional lebih melibatkan Notaris dalam pembuatan akta perjanjian / perikatan dibandingkan dengan bank syariah. Namun demikian, saat ini bank-bank syariah sebagai subsistem dari sistem perbankan nasional yang diatur secara khusus dalam UUPS juga menggunakan jasa hukum notaris di dalam setiap kegiatan bisnisnya, terutama yang terkait dengan Akta Akad Pembiayaan (AAP). Namun, hal yang perlu ditekankan disini adalah produk-produk bank syariah menggunakan prinsip-prinsip dan asas-asas hukum ekonomi syariah. Dengan kata lain, segala bentuk pencatatan perjanjian bisnis yang dituangkan dalam akta notarisnya pun harus pula merujuk kepada norma-norma hukum ekonomi syariah. ${ }^{7}$

Notaris yang memformulasikan akad pembiayaan syariah, diharapkan memperhatikan rukun dan syarat sahnya akad sebagaimana ditentukan syariat Islam, klausula yang tercantum pada setiap pasal akad syariah dapat dilihat konstruksi hukumnya telah sesuai atau tidak sesuai dengan hukum kontrak syariah.

Notaris dalam memformulasikan akta akad perbankan syariah, harus memperhatikan hal yang diatur didalam Undang-Undang Jabatan Notaris, serta pentingnya pemahaman di bidang perbankan syariah. Peraturan khusus mengenai bentuk akta syariah atau klausul akta akad syariah (kontrak) belum ada sampai sejauh ini. Pada prakteknya, akad yang dibuat antara pihak bank dan nasabah masih mengacu pada hukum positif, begitu juga akad pembiayaaan yang dibuat notariil. Bentuk akta akad syariah yang dibuat secara notariil agar dapat disebut sebagai akta otentik harus memenuhi ketentuan peraturan perundang-undangan yang berlaku, maka dari itu notaris dalam memformulasikan bentuk akta akad syariah wajib memperhatikan ketentuan Undang-Undang Jabatan Notaris. Dalam praktek, banyak Notaris yang membuat dan meresmikan akta akad syari'ah yang tidak memahami prinsip-prinsip syariah, ini terjadi terhadap Notaris yang sama 
sekali bukan seorang muslim dan hanya sekedar menerima order dari perbankan syariah yang bahkan tidak mengetahui sama sekali tentang rukun dan syarat sahnya akad berdasarkan syariah.

\section{Rumusan Masalah}

Dari latar belakang tersebut masalah yang dapat dirumuskan dalam penelitian ini adalah: Pertama, mengapa akad perbankan syariah pengikatan jaminannya masih menggunakan konsep perbankan konvensional? Kedua, bagaimana notaris memformulasikan akta akad Syariah yang sesuai dengan Undang-Undang Jabatan Notaris? Ketiga, bagaimana persyaratan ideal bagi notaris yang meresmikan akta akad perbankan syariah?

\section{Tujuan Penelitian}

Penelitian ini bertujuan untuk: pertama, mengetahui mengapa akad perbankan syariah pengikatan jaminan yang masih menggunakan konsep perbankan konvensional. Kedua, untuk mengetahui cara seorang notaris dalam memformulasikan akta akad syariah yang telah sesuai dengan Undang-Undang Jabatan Notaris. Ketiga, ditemukannya persyaratan ideal bagi notaris yang meresmikan akta akad perbankan syariah.

\section{Metode Penelitian}

Penelitian ini merupakan penelitian hukum normatif dengan pengolahan dan analisis data dengan cara deskriptif kualitatif. Data penelitian ini bersumber dari data sekunder yang berupa bahan hukum primer yang terdiri dari peraturan perundang-undangan antara lain: Undang-Undang Nomor 21 Tahun 2008 tentang Perbankan Syariah, Undang-Undang Nomor 2 Tahun 2014 jo Undang-Undang Nomor 30 Tahun 2004 tentang Jabatan Notaris, Undang-Undang Nomor 4 Tahun 1996 tentang Hak Tanggungan Beserta Benda-Benda yang Berkaitan dengan Tanah, buku-buku, jurnal, artikel dan literatur lain yang berkenaan dengan permasalahan yang dibahas, didukung dengan wawancara dari narasumber sebagai penunjang data sekunder. Adapun pendekatan yang digunakan dalam penelitian ini adalah pendekatan peraturan perundang-undangan. 


\section{Hasil Penelitian dan Pembahasan}

\section{Akad Syariah yang Pengikatan Jaminannya Masih Menggunakan Konsep Jaminan Perbankan Konvensional}

Pada perbankan syariah, tidak dikenal perjanjian kredit akan tetapi dikenal dengan pembiayaan sebagaimana tersebut dalam Pasal 1 Angka 25 UndangUndang Nomor 21 Tahun 2008 tentang Perbankan Syariah (untuk selanjutnya disebut UUPS) dan atas pembiayaan tersebut dapat diberikan agunan. Dalam ketentuan Pasal 1 Angka 25 UUPS ditegaskan bahwa: “Agunan adalah jaminan tambahan, baik berupa benda bergerak maupun benda tidak bergerak yang diserahkan oleh pemilik agunan kepada Bank Syariah dan/atau UUS, guna menjamin pelunasan kewajiban Nasabah Penerima Fasilitas."

Meskipun telah ada Undang-Undang Nomor 21 Tahun 2008 tentang Perbankan Syariah yang juga memerlukan barang atau benda jaminan tambahan, ternyata dalam penjaminan tersebut masih mempergunakan Undang-Undang Hak Tanggungan (UUHT), Surat Kuasa Membebankan Hak Tanggungan (SKMHT), serta Akta Pemberian Hak Tanggungan (APHT) yang tidak syariah dan juga belum ada lelang syariah. Contohnya dalam SKMHT dan UUHT misalnya masih ada kalimat pelunasan utang, perjanjian utang-piutang, kreditor, debitor dan kredit dalam lembaga perbankan yang melaksanakan kegiatan secara konvensional. Padahal, kata-kata tersebut tidak dikenal dalam akad perbankan syariah karena bergantung pada akad yang dibuat antara nasabah dan bank syariah. ${ }^{8}$

Pada prinsipnya hak tanggungan ada untuk tujuan menjamin pelunasan suatu utang/ kredit yang selama ini dikenal dalam sistem hukum keperdataan atau dalam hal ini adalah perbankan konvensional, akan tetapi dalam prakteknya perbankan syariah juga menggunakan lembaga hak tanggungan sebagai cara untuk mengikat jaminan atas tanah yang diberikan oleh nasabah/ penerima fasilitas pembiayaan kepada bank syariah. Padahal prinsip dan teori antara utang pada sistem konvensional dengan sistem pembiayaan pada perbankan syariah adalah berbeda.

${ }^{8}$ Habib Adjie dan Muhammad Hafidh, Akta Notaris untuk Perbankan Syariah, Citra Aditya Bakti, Bandung, 2017, hlm. 68-69 
Dari definisi yang ada di dalam Undang-Undang Perbankan dan UndangUndang Perbankan Syariah tersebut di atas dapat disimpulkan bahwa utang / kredit dan pembiayaan keduanya merupakan bentuk fasilitas penyediaan dana yang diberikan oleh perbankan, akan tetapi secara prinsip utang / kredit (dalam perbankan konvensional) dengan pembiayaan (dalam perbankan syariah) secara garis besar merupakan suatu hal yang sangat berbeda. Perbedaan itu dapat dilihat dari keuntungan atau imbalan yang diterima oleh bank atas penyediaan dana yang bank berikan. Pada kredit / utang yang diberikan oleh bank konvensional pengembalian atas dana yang dipinjamkan disertai dengan adanya pemberian bunga, sedangkan di dalam perbankan syariah tidak dikenal bahkan dilarang adanya pemberian bunga/riba. ${ }^{9}$

Selain itu, pembiayaan dalam perbankan syariah tidak mutlak sama dengan utang/ kredit. Dalam perbankan konvensional penyediaan dana mutlak merupakan utang / kredit, sedangkan di dalam perbankan syariah penyediaan dana tidak mutlak merupakan utang / kredit, akan tetapi harus dilihat dulu bentuk akad - akad dalam perbankan syariah itu sendiri. Akad yang paling sering dijumpai dalam prakteknya pada perbankan syariah diantaranya adalah akad musyarakah, mudharabah dan murabah. ${ }^{10}$ Akad - akad yang ditawarkan oleh perbankan syariah tersebut tidaklah sama dengan utang/ kredit. Musyarakah merupakan akad kerjasama diantara dua pihak atau lebih untuk suatu usaha tertentu yang masing - masing pihak memberikan porsi dana dengan ketentuan bahwa keuntungan akan dibagi sesuai dengan kesepakatan, sedangkan kerugian ditanggung sesuai dengan porsi dana masing masing. ${ }^{11}$ Mudharabah merupakan akad kerja sama suatu usaha antara pihak pertama (malik, shahibul mal, atau bank syariah) yang menyediakan seluruh modal dan pihak kedua ('amil, mudharib, atau nasabah) yang bertindak selaku pengelola dana dengan membagi keuntungan usaha sesuai dengan kesepakatan yang dituangkan dalam akad, sedangkan kerugian ditanggung sepenuhnya oleh bank syariah kecuali jika pihak kedua melakukan kesalahan yang disengaja, lalai atau menyalahi perjanjian. ${ }^{12}$

\footnotetext{
${ }^{9}$ Agus Triyanta, Hukum Perbankan Syariah, Setara Press, Malang, 2016, hlm. 43

${ }^{10}$ Akhmad Mujahidin, Hukum Perbankan Syariah, Rajawali Press, Jakarta, 2016, hlm. 83

${ }^{11}$ Penjelasan Pasal 19 ayat (1) huruf c UUPS

${ }^{12}$ Mardani, Hukum Bisnis Syariah, Kencana, Jakarta, 2014, hlm. 138
} 
Akad murabahah adalah akad pembiayaan suatu barang dengan menegaskan harga belinya kepada pembeli dan pembeli membayarnya dengan harga yang lebih sebagai keuntungan yang disepakati. ${ }^{13}$ Sehingga jika melihat bentuk - bentuk akad pembiayaan tidaklah tepat jika dipersamakan dengan utang piutang seperti hal nya yang ada di perbankan konvensional. Akad mudharabah dan musyarakah didasarkan pada prinsip kerjasama antara bank dengan nasabah, sedangkan murabahah dasarnya adalah jual- beli, sehingga tidaklah tepat jika keduanya dipersamakan antara akad pembiayaan dan utang piutang. Walaupun kenyataanya didalam praktek, kedua perbuatan hukum tersebut yakni akad pembiayaan dan utang-piutang diperlakukan sama, yakni sama-sama menggunkan jaminan hak tanggungan sebagimana diatur di dalam UUHT.

Dalam praktik saat ini, pengikatan jaminan atas akad-akad syariah menarapkan aturan dalam Undang-Undang Hak Tanggungan sebagaimana perbankan konvensional. Pada bank syariah jaminan hak tanggungan digunakan untuk menambah kepercayaan masyarakat dengan melihat nasabah beserta usahanya agar dapat meyakinkan pihak bank syariah. ${ }^{14}$

Akad pembiayaan pada perbankan syariah tidaklah dapat dipersamakan dengan utang, maka tidak tepat apabila akad pembiayaan dijamin dengan jaminan hak tanggungan. Dasar adanya hak tanggungan sebagaimana diatur dalam UUHT yaitu untuk menjamin pelunasan utang tertentu, maka tidak dapat dijadikan dasar atau landasan untuk menjamin pemenuhan kewajiban nasabah yang melakukan akad pembiayaan di perbankan syariah, karena secara prinsip utang/ kredit dengan akad pembiayaan adalah suatu hal yang berbeda.

Peraturan mengenai klausul jaminan pada akad syariah masih hangat menjadi perbincangan praktisi maupun akademisi, hal tersebut terkait dengan ketentuan jaminan yang mengakibatkan adanya ketidakselarasan antara akad pokok dan perjanjian tambahannya (jaminannya). Dimana perjanjian pokok di dalam akad pembiayaan syariah tidak menggunakan istilah kreditur maupun debitur, karena akad pembiayaan di bank syariah memiliki perbedaan dengan

${ }^{13}$ Penjelasan Pasal 19 ayat (1) huruf c UUPS

${ }^{14}$ Dewi Nurul Musjtari, Rekonstruksi Lembaga Penyelesaian Sengketa Akad Pembiayaan Dengan Jaminan Hak Tanggungan Pasca Putusan Mahkamah Konstitusi Nomor 93/PUU-X/201, Media Hukum,Vol. 23 No. 1, 2016, hlm. 69 
perjanjian kredit. Pembiayaan pada bank syariah timbul karena adanya kerjasama, lain halnya dengan perjanjian kredit yang pada prinsipnya adalah hutang. Tetapi dewasa ini kedua perbuatan hukum yang berbeda tersebut diperlakukan sama. Sama-sama menggunakan konsep jaminan konvensional, yakni seperti hak tanggungan ${ }^{15}$ dan fidusia.

Sejauh peneliti telusuri, belum ada ketentuan atau peraturan yang mengatur soal penjaminan yang untuk akad pembiayaan syariah. Tidak diaturnya jaminan syariah dalam perundang-undangan menimbulkan kekosongan hukum, maka tidak heran jika dalam praktek perbankan syariah masih memberlakukan prosedur jaminan seperti yang ada di perbankan konvensional.

Ketidakharmonisan tersebut (akad murabahah/ jual-beli sebagai perjanjian pokok diikuti dengan pemasangan hak tanggungan) selama ini memang tidak dipermasalahkan oleh para praktisi di bidang perbankan syariah, karena berdasarkan Undang-Undang Hak Tanggungan pengikatan jaminan itu merupakan perjanjian ikutan/ acessoir dari hubungan hukum perutangan atau yang menimbulkan utang. Bahkan, kedua prinsip yang berbeda itu didalam praktek diperlakukan sama. Hal tersebut yang kemudian menjadi bahan yang selalu dibahas dan dikaji secara akademis.

\section{Formulasi Akta Notaris pada Akta Akad Syariah yang Sesuai dengan Undang- Undang Jabatan Notaris}

Notaris adalah pejabat umum yang berwenang untuk membuat akta otentik sejauh pembuatan akta otentik tertentu tidak dikhususkan bagi pejabat umum lainnya. Akta otentik sebagai alat bukti terkuat dan terpenuh mempunyai peranan penting dalam setiap hubungan hukum dalam kehidupan masyarakat. Kedudukan seorang notaris sebagai suatu fungsionaris (jabatan) dalam masyarakat hingga sekarang masih disegani. Seorang notaris biasanya dianggap sebagai seorang pejabat tempat seorang dapat memperoleh nasihat, segala sesuatu yang ditulis dan ditetapkannya (konstatir) adalah benar, hal ini dikarenakan notaris merupakan

${ }^{15} \mathrm{Akad}$ Pembiayan yang dibebani agunan atau jaminan benda tidak bergerak atau benda tetap masih tunduk pada Undang-Undang Nomor 4 Tahun 1996 tentang Hak Tanggungan Atas Tanah Beserta Benda-Benda yang Berkaitan dengan Tanah yang Pasal 1 ayat (1) menentukan hak tanggungan adalah hak jaminan yang di bebankan pada hak atas tanah untuk pelunasan utang tertentu. 
pembuat dokumen yang kuat dalam suatu proses hukum, sehingga perlu kecerdasan, kecermatan dan kehaati-hatian dalam proses pembuatan akta agar tidak terjadi kesalahan yang akan berpotensi menimbulkan sengketa di kemudian hari. ${ }^{16}$

Notaris dalam memformulasikan akta akad perbankan syariah, harus memperhatikan dan menerapkan hal yang diatur didalam Undang-Undang Jabatan Notaris, serta pentingnya pemahaman di bidang perbankan syariah. Di dalam praktek, akta pembiayaan pada perbankan syariah dapat dibuat dalam dua jenis, yakni akta yang dibuat di bawah tangan dan akta yang dibuat secara notariil. Peraturan khusus mengenai bentuk akta syariah atau klausul akta akad syariah (kontrak) belum ada sampai sejauh ini. Pada prakteknya, akad yang dibuat antara pihak bank dan nasabah masih mengacu pada hukum positif, begitu juga akad pembiayaaan yang dibuat notariil.

Akad pembiayaan yang dibuat secara notariil, agar dapat disebut sebagai akta otentik harus memenuhi ketentuan Pasal 1868 KUH Perdata, yang muatannya sebagai berikut:

"suatu akta otentik ialah suatu akta yang dibuat dalam bentuk yang ditentukan undang-undang oleh atau dihadapan pejabat umum yang berwenang untuk itu di tempat akta itu dibuat"

Unsur- unsur dari Pasal tersebut di atas dapat dijelaskan sebagai berikut, pertama, akta dibuat dalam bentuk yang ditentukan Undang-Undang. Kedua, dihadapan pejabat umum yang berwenang untuk itu di tempat akta itu dibuat.

Seorang notaris mempunyai tanggung jawab terhadap akta akad pembiayaan perbankan syariah yang dibuat di hadapannya secara otentik. Terhadap akta akad tersebut, Notaris mempunyai tanggung jawab penuh tentang kebenaran dan ketepatan konstruksi akad agar terpenuhinya syarat subyektif maupun obyektif atas akad/perjanjian tersebut, sehingga akta akad yang dibuat di hadapan notaris tersebut benar dan secara otentik sangat mendasar menjadi akta akad yang mempunyai kekuatan nilai pembuktian yang sempurna. Notaris dalam hlm. 7-10

${ }^{16}$ M. Luthfan Hadi Darus., Hukum Notariat dan Tanggungjawab Jabatan Notaris, UII Press, Yogyakarta, 2017, 
memformulasikan akta akad atas permintaan para pihak berdasar pada tata cara atau mekanisme / prosedur pembuatan akta notaris.

Apabila para pihak menganggap ada yang tidak benar dari akta tersebut dan menderita kerugian sebagai akibat langsung dari akta tersebut maka pihak dimaksud harus menggugat notaris dan wajib membuktikan apakah akta notaris tersebut tidak memenuhi aspek lahiriah, formal atau materiil dan membuktikan kerugiannya. Notaris harus bertanggung jawab penuh atas konstruksi akta akad sejak akta akad tersebut diformulasikan ke dalam akta, sehingga jika terjadi sengketa pada akta akad yang dinyatakan tidak sah dan/atau batal demi hukum yang merujuk pada mekanisme pembuatan akta akadnya, notaris harus mempertanggungjawabkannya, bahkan ketika kemudian oleh hakim memutuskan untuk membayar ganti rugi yang diderita oleh para subyek sebagai akibat langsung dari adanya kesalahan konstruksi akta akad yang dibuat oleh notaris. Oleh karenanya notaris perlu memperhatikan dengan seksama bagaimana bentuk akta akad yang dibuat di hadapannya agar sesuai serta tidak melanggar ketentuan yang telah ditetapkan dalan UUJN-P. ${ }^{17}$

Akta pembiayaan di bank syariah yang dibuat secara notariil harus mengikuti bentuk yang ditentukan oleh Undang-Undang, dalam hal ini adalah UndangUndang Nomor 2 Tahun 2014 tentang Perubahan atas Undang-Undang Nomor 30 Tahun 2004 tentang Jabatan Notaris. Pasal yang mengatur bentuk akta dijelaskan dalam Pasal 38 yang muatannya berbunyi:

(1) Setiap Akta terdiri atas:
a. Awal akta atau kepala akta;
b. Badan akta; dan
c. Akhir atau penutup akta.

(2) Awal Akta atau kepala Akta memuat:
a. Judul akta;
b. Nomor akta;
c. Jam, hari, tanggal, bulan, dan tahun; dan
d. Nama lengkap dan kedudukan Notaris

\footnotetext{
${ }^{17}$ Pandam Nurwulan, "Akad Syariah Berdasar Hukum Ekonomi Islam dan Aplikasinya dalam Akta Notaris”, Makalah, Program Doktor Ilmu Hukum, Fakultas Hukum Universitas Islam Indonesia, Yogyakarta, 2017 hlm.12
} 
(3) Badan Akta memuat:

a. Nama lengkap, tempat dan tanggal lahir, kewarganegaraan, pekerjaan, jabatan, kedudukan, tempat tinggal para penghadap dan/atau orang yang mereka wakili;

b. Keterangan mengenai kedudukan bertindak penghadap;

c. Isi akta yang merupakan kehendak dan keinginan dari pihak yang berkepentingan; dan

d. Nama lengkap, tempat daan tanggal lahir, serta pekerjaan, jabatan, kedudukan, dan tempat tinggal dari tiap-tiap saksi pengenal.

(4) Akhir atau penutup Akta memuat:

a. Uraian tentang pembaacaan akta sebagaimana dimaksud dalam Pasal 16 ayat (1) huruf $m$ atau pasal 16 ayat (7);

b. Uraian tentang penandatanganan dan tempat penandatanganan atau penerjemahan akta jika ada;

c. Nama legkap, tempat dan tanggal lahir, pekerjaan, jabatan, kedudukan, dan tempat tinggal dari tiap-tiap saksi Akta; dan

d. Uraian tentang tidak adanya perubahan yang terjadi dalam pembuatan Akta atau uraian tentang adanya perubahan yang dapat berupa penambahan, pencoretan, atau penggantian serta jumlah perubahannya.

(5) Akta Notaris Pengganti dan Pejabat Sementara Notaris, selain memuat ketentuan sebagaimana dimaksud pada ayat (2), ayat (3), dan ayat (4), juga memuat nomor dan tanggal penetapan, pengangkatan, serta pejabat yang mengangkatnya.

Undang-Undang Jabatan Notaris bersifat umum, tidak hanya menjadi pedoman bagi akta secara umum, tetapi juga menjadi pedoman bagi akta di bidang Perbankan Syariah, mengingat peraturan mengenai akta di bidang perbankan syariah belum diatur secara khusus.

Dalam tataran praktek, ada notaris yang mencantumkan kalimat "Bismillahirrahmanirrahim" di awal akta dan "Alhamdulillahirabbilalamin" di akhir atau penutup akta pada akad pembiayaan syariah. Dalam melakukan hal tersebut bukan tanpa alasan, salah satu alasannya adalah membedakan bahwa akta yang dibuatnya adalah akta pembiayaan syariah, serta sejatinya bagi seorang muslim, penggunaan kalimat seperti tersebut di atas dalam setiap memulai kegiatan adalah lumrah atau wajar, karena muslim terbiasa dalam mengamalkan kalimat Bismillah sebagai niat yang murni, yang menunjukan niat melakukan sesuatu karena Allah. ${ }^{18}$ Sama halnya dengan menambah kalimat "Alhamdulillahirabbilalamin" pada akhir

${ }^{18}$ Wawancara dengan Ny. Agus Praptini, Notaris Kota Yogyakarta, Yogyakarta 08 Desember 2017 
atau penutup akta, pemberian kalimat tersebut juga bertentangan dengan Pasal 38 UUJNP.

Pasal 38 secara jelas mengatur mengenai awal akta atau kepala akta, isi akta, serta akhir atau penutup akta, sehingga apabila ada akta yang tidak sesuai dengan pasal tersebut dapat dianggap melanggar UUJN dan kehilangan keotentikan sebuah akta. Akta notaris tersebut menjadi tidak otentik karena tidak dibuat dalam bentuk yang sesuai dengan undang-undang. Hal ini sesuai dengan Pasal 41 UUJN yang muatannya berbunyi: "Pelanggaran terhadap ketentuan sebagaimana dimaksud dalam Pasal 38, Pasal 39, dan Pasal 40 mengakibatkan akta hanya mempunyai kekuaatan pembuktian sebagai akta di bawah tangan"

Sebagaimana penelitian yang dilakukan oleh Febriyanti Dwi Putri dalam tesisnya yang berjudul "Kedudukan Akta Perbankan Syariah yang dibuat oleh Notaris menurut UU No. 2 Tahun 2014 tentang Perubahan Atas UU No. 30 Tahun 2004 tentang Jabatan Notaris" memberi kesimpulan bahwa Akta Notaris di bidang perbankan syariah yang mencantumkan "Bismiilahirrahmanirrahim" di awal aktanya bertentangan dengan Undang-Undang Jabatan Notaris dan memiliki kedudukan sebagai akta tidak otentik yakni mempunyai kekuatan pembuktian yang tidak sempurna sebagaimana akta di bawah tangan. ${ }^{19}$

Penulis memiliki pendapat yang sama dengan penelitian di atas yang memberi kesimpulan bahwa akta Notaris dibidang perbankan syariah yang mencantumkan "Bismillahirrahmanirrahim" di awal akta adalah bertentangan dengan Undang-Undang Jabatan Notaris, sehingga hanya mempunyai kekuatan sebagaimana akta dibawah tangan.

Pencantuman kalimat seperti tersebut pada awal akta perbankan syariah tidak selaras dengan ketentuan Pasal 38 ayat (2) UUJNP dan dapat disimpulkan bahwa akta tersebut telah cacat hukum dalam segi formalitas atau bentuknya karena salah satu syaratnya tidak dipenuhi, kedudukan akta seperti itu terdegradasi kedudukannya dari akta otentik menjadi mempunyai nilai kekuatan pembuktian sebagai akta dibawah tangan sesuai dengan ketentuan Pasal 1869

${ }^{19} \mathrm{http}$ // notariat.fh.unsri.ac.id/userfiles/file/FEBRIYANTI\%20DWI\%20PUTRI\%2002022681418036.p df diakses pada 07 Desember 2017 
KUHPerdata. ${ }^{20}$ Pasal 1869 KUHPerdata telah menentukan batasan akta otentik (akta Notaris) yang mempunyai nilai kekuatan pembuktian sebagai akta di bawah tangan dapat terjadi jika tidak memenuhi ketentuan karena:

(1) Tidak berwenangnya pejabat umum yang bersangkutan,

(2) Tidak mampunyai pejabat umum yang bersangkutan, atau

(3) Cacat dalam bentuknya.

Meskipun demikan, akta seperti itu tetap mempunyai kekuatan pembuktian sebagai akta dibawah tangan jika akta tersebut ditandatangani dan diakui oleh para pihak.

Agar tidak melanggar ketentuan Pasal 38 UUJN dengan menambahi kalimat Bismillah di awal akta dan memiliki resiko akta menjadi terdegradasi menjadi akta tidak otentik dan memiliki kekuatan pembuktian seperti akta di bawah tangan, kalimat Bismillahirrahmanirrahim dapat di letakkan pada bagian isi akta. Isi akta memuat kehendak dan keinginan dari pihak yang berkepentingan, terlebih lagi pihak dalam posisi lingkup perbankan syariah.

Sudah seharusnya dan semestinya akta syariah yang merupakan produk perbankan syariah yang akan diformulasikan secara otentik ke dalam akta notaris hendaknya dibuat berdasar dan sesuai dengan UUJNP yaitu dalam Pasal 38 ayat (2). Hal tersebut dapat dilakukan oleh seorang Notaris dengan cara memindahkan dan/atau meletakkan ketentuan ketentuan kalimat yang menjadi landasan syariah dari sifat/jenis akta akad syariah baik berdasar Al-Qur'an maupun Hadist pada bagian isi akta atau pada akhir praemisse.

Jika kemudian dibuat dalam format otentik akta maka harus menyesuaikan dengan ketentuan sebagaimana diatur Pasal 38 ayat (2) UUJNP. Bahwa awal dan akhir akta merupakan mutlak tanggungjawab notaris, ${ }^{21}$ sedang isi akta merupakan kesepakatan tertulis yang dikehendaki oleh para pihak sepanjang berdasarkan peraturan perundangan yang berlaku/ sesuai prinsip syariah sehingga formulasinya adalah sebagai berikut:

${ }^{20}$ Habib Adjie dan Muhammad Hafidh, Op. Cit., hlm. 59

${ }^{21}$ Habib Adjie dan Muhammad Hafid, Akta Notaris untuk Perbankan Syariah, (Bandung : Citra Aditya Bakti, 2017), hlm. 68 


\section{AKAD PEMBIAYAAN AL-MURABAHAH}

Pada hari ini,

No:

Tanggal

Bulan

Tahun

Pukul

WIB (Waktu Indonesia Barat),

Menghadap kepada saya,

Selanjutnya kedua belah pihak sepakat menuangkan akad ini dengan Akad Pembiayaan Al-Murabahah dalam aktai ni (selanjutnya disebut "Akad") dengan memakai syarat-syarat dan ketentuan-ketentuan dan diawali dengan kalimat sebagai berikut:

Bismillahirrahmanirrahim

---- “Dan Allah Swt, telah menghalalkan jual beli dan mengharamkan riba ----(Surat Al-Baqarah 2: 275)

" Hai orang-orang beriman, janganlah kamu makan harta sesama kamu dengan jalan bathil, kecuali melaluip erniagaan yang berlaku dengan suka sama suka diantara kamu:"(Surat An-Nisa' 4: 29)

ISI AKTA-

Dan pada akhir akta sebelum kalimat penutup akta dapat pula dicantumkan kalimat sebagai berikut:22

Pada akhirnya para penghadap telah sepakat menutup akta ini dengan kalimat-----------

\section{Alhamdulillahirabbilalamin} DEMIKIAN AKTA INI

Bahwa pada dasarnya pencantuman kalimat-kalimat sebagaimana pada bagian premise/ awal akta akad syariah, maka secara formalitas akta akad di atastelah sesuai dengan ketentuan Pasal 38 UUJNP ayat (2) dan secara substansi telah sesuai dengan prinsip syariah, sehingga label autentik atas akta akad tersebut yang dibuat dihadapan notaris betul-betul mendasar serta dapat dipertanggungjawabkan sehingga bila notaris telah melaksanakan ketentuan dimaksud aktanya akan betul-betul mempunyai nilai kekuatan pembuktian yang sempurna baik secara lahiriah, formil maupun materiil. Isi dari akad adalah kesepakatan para pihak. Dalam memformulasikan isi atau membuat kerangka akta yang dikehendaki para pihak, notaris wajib menerapkan amanat UUJNP mengenai kewenangan dan kewajiban Notaris.

${ }^{22}$ Ibid., hlm. 70 
Pada praktiknya, bank telah menyiapkan formulasi sendiri dalam membuat akad pembiayaan, selanjutnya diserahkan kepada notaris yang disertai surat order untuk dibuatkan menjadi notariil akta. Walaupun pihak bank telah menyiapkan sendiri draft dari akadnya, notaris tetap membuat kerangka akta, hal ini adalah bentuk dari kecermatan dan kehati-hatian notaris dalam membuat akta.

Pada prakteknya, ketentuan dan klausul-klausul yang terdapat pada akta pembiayaan di bidang perbankan syariah masih mengacu pada hukum positif dan masih memakai istilah perjanjian konvensional seperti :

(1) Pembebanan/ Agunan/ Jaminan yang berupa Hak Tanggungan, Fidusia, Cash Collaterall, Gadai, Personal Guarantee, dll,23

(2) Angsuran;

(3) Surat sanggup; ${ }^{24}$

(4) Pembayaran kembali/ pelunasan utang;

(5) Biaya, Potongan dan Pajak;

(6) Cedera janji/ akibat cedera janji;

(7) Force majeur; ${ }^{25}$

(8) Risiko dan Asuransi;

(9) Penyelesaian sengketa; dll.

Dalam membuat kontrak pembiayaan bank syariah masih banyak mengacu pada format perjanjian kredit di bank konvensional, namun demikian dilakukan juga penyesuaian dalam pasal-pasalnya agar tidak bertentangan dengan prinsipprinsip syariah. Penyesuaian yang dilakukan berpedoman pada hukum Islam yang berlaku, dan juga mengacu juga kepada ketentuan hukum positif Indonesia. Yang harus diperhatikan dalam pembuatan akad antara lain Undang-Undang tentang Perbankan Syariah, Undang-Undang Perseroan Terbatas, Surat Keputusan Direksi Bank Indonesia, Fatwa Dewan Syariah Nasional (DSN), dan lain sebagainya. ${ }^{26}$

\footnotetext{
${ }^{23}$ Ketentuan jaminan didalam akad pembiayaan syariah masih menggunakan konsep jaminan seperti di perbankan konvensional, hal ini dikarenakan peraturan mengenai konsep jaminan yang dikhususkan untuk perbankan syariah belum ada. Dalam perbankan syariah, jaminan dimaksudkan untuk kebaikan dan keamanan bagi kedua belah pihak (bank dan nasabah).

${ }^{24}$ Ketentuan adanya surat sanggup pada akad pembiayaan syariah memiliki tujuan yang sama dengan perjanjian kredit di bank konvensional, yakni bertujuan untuk mempertegas bahwa nasabah sanggup melaksanakan seluruh kewajibannya

${ }^{25}$ Harus diakuibahwaperaturantentangforce majeuredalamakadsyariahmasihmenjadi barang langkasehinggajelas-jelastidakmengakomodasikepentingannasabah.Lihat Rifqi Hidayat Muhammad (2015) Analisis Hukum Kontrak Syariah Terbadap Klausul Force Majeure Dalam Akad Murabahah. Tesis, Pascasarjana. IAIN Antasari Banjarmasin, link:http://idr.iain-antasari.ac.id/178/, diaksestanggal 3 Februari 2017.

${ }^{26}$ Aunur Rohim Faqih, Bank Syariah, Kontrak Bisnis Syariab \& Penyelesaian Sengketa di Pengadilan, (Yogyakarta: FH UII Press, 2017), hlm. 205-206
} 
Notaris dalam menjalankan tugas jabatannya mengikuti ketentuan hukum yang berlaku, di dalam praktek bisnis perbankan syariah belum ada peraturan khusus mengenai akad pembiayaan syariah termasuk ketentuan yang membatasi mengenai klausul-klausul pembiayaan, maka dari itu notaris tidak dituntut untuk menambahi atau merubah sendiri ketentuan dan kebiasaan yang selama ini dipraktekan. Sampai saat ini ini notaris mematuhi ketentuan-ketentuan UndangUndang Jabatan Notaris dan ketentuan umum mengenai perbankan syariah.

Klausula yang ada di dalam akad meskipun masih mengacu pada hukum positif, selama tidak bertentangan dengan syar'i dan juga ada nilai maslahatnya dapat diterima oleh hukum Islam. Bentuk akad/kontrak seperti apapun jika belum ada ketentuan yang melarangnya maka itu sah, karena hakekat dari perjanjian itu sendiri adalah menurut maksud/ tujuan dan maknanya, bukan menurut lafadz, bentuk serta susunan katanya atau redaksinya. ${ }^{27}$

\section{Persyaratan Ideal Bagi Notaris yang Meresmikan Akta Akad Perbankan Syariah}

Kantor cabang bank syariah yang memiliki banyak aktivitas pembiayaan secara otomatis banyak membutuhkan jasa notaris sebagai pejabat umum yang berwenang membuat akta-akta otentik. Tidak semua bank syariah memiliki persyaratan ideal untuk seorang notaris yang bermitra dengannya, baik itu persyaratan agama maupun latar belakang pendidikan.

Dalam tataran praktek, Bank BNI Syariah Yogyakarta dan Bank BPD Syariah Yogyakarta sama-sama memiliki kriteria atau syarat khusus bagi notaris yang akan menjadi rekanannya, yakni salah satunya adalah bahwa notaris yang menjadi rekanan bank tersebut telah memiliki sertifikasi pelatihan pembiayaan syariah, tetapi tidak ada syarat bahwa notaris tersebut haruslah seorang notaris muslim. Hal ini dikemukakan alasan bahwa setiap notaris menurut Undang-Undang yang berlaku, tidak ada pembatasan kewenangan yang diberikan mengenai agama seorang notaris dalam mengesahkan akta terkait transaksi pembiayaan di bank syariah. Tetapi walaupun tidak ada syarat mutlak mengenai agama notaris yang menjadi rekanannya, bank BNI Syariah Yogyakarta dan Bank BPD Syariah

${ }^{27}$ Ibid., hlm. 218. 
Yogyakarta akan mengutamakan menerima rekan seorang notaris yang beragama Islam. ${ }^{28}$

Notaris yang saat ini menangani akad bisnis di bank syariah, banyak yang mengikuti pelatihan sertifikasi syariah, karena beberapa bank syariah di Yogyakarta mensyaratkan bahwa notaris yang menjadi rekanannya wajib terlebih dahulu mengikuti pelatihan sertifikasi syariah. ${ }^{29}$

Perbuatan hukum yang dilakukan bank syariah dan nasabah dalam rangka pembiayaan, khususnya dalam bidang pembuatan akta di bank syariah diperlukan pemahaman yang mendalam mengenai ilmu ekonomi syariah, hal-hal yang perlu diperhatikan mengenai akad, harus dipelajari dan difahami sebagai dasar mutlak dalam membuat akta syariah.

Menurut Habib Adjie, notariat atau jabatan notaris adalah lembaga yang netral sehingga tidak hanya notaris muslim yang dapat membuat akta perbankan syariah, tetapi juga Notaris yang beragama kristen, katholik, hindu, budha atau agama dan kepercayaan lain pun mempunyai hak yang sama untuk membuat akta perbankan syariah sepanjang semua prosedur dan tata cara pembuatan akta menurut UUJN/UUJNP dipenuhi. ${ }^{30}$ Sesuai ketentuan Pasal 15 ayat (1) UUJN-P, Notaris untuk membuat akta yang diperintahkan oleh Undang-Undang atau yang dikehendaki oleh para pihak agar tindaknnya dituangkan ke dalam bentuk akta Notaris. Dengan demikian, Notaris berwenang membuat akta apa saja sebagaimana diatur salam Pasal 15 ayat (1) UUJN-P. ${ }^{31}$

Data Tabel diambil dan diolah dari narasumber dalam penelitian ini sebagai berikut:

28Pandam Nurwulan dan Ina Faturohmah, "Akad Perbankan Syariah dan Penerapannya dalam Akta Notaris yang sesuai dengan Undang-Undang Jabatan Nortaris", Penelitian Kolaborasi, Program Pasca Sarjana Fakultas Hukum Universitas Islam Indonesia, 2017, hlm.73.

${ }^{29}$ Ibid., hlm. 76.

${ }^{30} \mathrm{Habib}$ Adjie dan Muhammad Hafidh, Op. Cit., hlm. 71

${ }^{31} \mathrm{Ibid}$., hlm. 71 
Tabel 1

Pandangan Notaris mengenai Notaris yang meresmikan akad pembiayaan di Bank Syariah 32

\begin{tabular}{lcc}
\hline \multicolumn{1}{c}{ Unsur } & $\begin{array}{c}\text { Apakah Notaris yang meresmikan akad } \\
\text { pembiayaan syariah di bank Syariah } \\
\text { haruslah Notaris yang beragama Islam }\end{array}$ \\
\cline { 2 - 3 } & Harus & Tidak \\
\hline M. Firdauz Ibnu Pamungkas, S.H & $\sqrt{ }$ & $\sqrt{ }$ \\
Diana Hexa Dewi, S.H & & $\sqrt{ }$ \\
Agus Praptini, S.H & & \\
\hline
\end{tabular}

Data Tabel diambil dan diolah dari narasumber dalam penelitian ini sebagai berikut:

Tabel 2

Pandangan Bank Syariah Terkait Notaris yang meresmikan Akad Pembiayaan Syariah ${ }^{33}$

\begin{tabular}{|c|c|c|c|}
\hline \multirow[t]{2}{*}{ Unsur } & \multicolumn{2}{|c|}{$\begin{array}{l}\text { Apakah Notaris yang } \\
\text { meresmikan akad } \\
\text { pembiayaan syariah di } \\
\text { bank Syariah haruslah } \\
\text { Notaris Muslim }\end{array}$} & $\begin{array}{c}\text { Persyaratan menjadi } \\
\text { Notaris Rekanan Bank } \\
\text { harus mengikuti Pelatihan } \\
\text { atau Sertifikasi } \\
\text { pembiayaan Syariah }\end{array}$ \\
\hline & Harus & Tidak & Tidak \\
\hline $\begin{array}{c}\text { Bank BNI Syariah } \\
\text { Yogyakarta }\end{array}$ & & $\sqrt{ }$ & $\sqrt{ }$ \\
\hline $\begin{array}{c}\text { Bank BPD Syariah } \\
\text { Yogyakarta }\end{array}$ & & $\sqrt{ }$ & $\sqrt{ }$ \\
\hline $\begin{array}{c}\text { Bank Muammalat } \\
\text { Yogyakarta }\end{array}$ & $\sqrt{ }$ & & $\sqrt{ }$ \\
\hline
\end{tabular}

Dari kedua tabel di atas menunjukkan bahwa terdapat perbedaan pendapat untuk Notaris yang meresmikan akad syariah tidak harus muslim, ironisnya justru pada Bank Syariah yang tidak mensyaratkan Notaris yang meresmikan akad syariah adalah Notaris Muslim.

Meskipun terdapat perbedaan pendapat, namun merupakan hal ideal apabila Notaris yang meresmikan akta akad perbankan syariah adalah seorang muslim, dengan pemahaman yang baik hal dalam prinsip-prinsip syariah. Hal demikian

${ }^{32}$ Pandam Nurwulan dan Ina Faturohmah, Akad Perbankan Syariah dan Penerapannya dalam Akta Notaris yang sesuai dengan Undang-Undang Jabatan Notaris,Penelitian Kolaborasi, Program Pasca Sarjana Fakultas Hukum Universitas Islam Indonesia, Yogyakarta, 2017, hlm. 76

${ }^{33} \mathrm{Ibid}$., hlm. 76 
perlu dipahami baik oleh para Notaris dan pengelola perbankan syariah sehingga dalam memberikan pelayanan kepada masyarakat yang membuat hubungan hukum (akad-akad syariah pada perbankan syariah) betul-betul mengacu pada prinsip-prinsip/ konsep syariah yang benar-benar syari (mengikuti ketentuan rukun, syarat, dan asas dalam akad syariah) sehingga tidak hanya pada namanya saja (akad syariah dan perbankan syariah).

\section{Penutup}

Akad perbankan syariah pengikatan jaminannya masih menggunakan konsep jaminan perbankan konvensional karena belum ada ketentuan/regulasi secara syariah yang mengatur tentang pengikatan jaminan untuk akad-akad syariah (ada kekosongan hukum/recht vacuum). Dengan demikian di dalam praktek prosedur pengikatan jaminan untuk akta-akta akad syariah memakai hak tanggungan dan fidusia, sebagaimana yang lazim digunakan oleh perbankan konvensional.

Notaris dalam memformulasikan akta akad syariah yang dibuat secara notariil formulasi bentuknya harus sesuai dengan Pasal 38 Undang-Undang Jabatan Notaris dengan tanpa meninggalkan prinsip-prinsip syariah serta mekanisme/prosedur pembuatan akta notaris. Notaris yang meresmikan akta-akta akad syariah harus paham betul terhadap prinsip-prinsip syariah, sehingga menjadi ideal jika seorang notaris yang meresmikan akta-akta akad syariah adalah seorang muslim.

Saran dari peneliti adalah sehubungan dengan belum diaturnya ketentuan jaminan syariah pada lembaga perbankan syariah menimbulkan kekosongan hukum (rechts vacuum).Untuk mengisi kekosongan hukum yang dimaksud, pemerintah (dalam hal ini dapat dilakukan oleh OJK), untuk membuat regulasi mengenai pengikatan jaminan terhadap kegiatan ekonomi yang benar-benar tunduk terhadap prinsip syariah yang saat ini sudah menjadi kebutuhan masyarakat. Notaris dalam memformulasikan akta-akta akad syariah wajib memperhatikan dan mengacu pada bentuk akta yang diatur dalam UndangUndang Jabatan Notaris. Notaris yang menangani akta-akta akad syariah sebaiknya seorang muslim yang paham betul mengenai prinsip-prinsip syariah. 


\section{Daftar Pustaka}

\section{Buku}

Adjie Habib dan Hafidh Muhammad, Akta Notaris untuk Perbankan Syariah, Citra Aditya Bakti, Bandung, 2017.

Aidil, Ustad, Mengenal Notaris Syariah, Citra Aditya Bakti, Bandung, 2011

Darus, M. Luthfan Hadi., Hukum Notariat dan Tanggungjawab Jabatan Notaris, Yogyakarta, UII Press, 2017.

Faqih, Aunur Rohim, “Kontrak Bisnis Syariah Studi Mengenai Penerapan PrinsipPrinsip Syari'ah dalam Pembiayaan Pada Bank Syariah di Indonesia", Ringkasan Desertasi, Program Doktor (S-3) Ilmu Hukum Universitas Islam Indonesia, 2014.

Bank Syariah, Kontrak Bisnis Syariah E Penyelesaian Sengketa di Pengadilan, FH UII Press, 2017.

Hafidah, Noor, Hukum Jaminan Syariah; Implementasinya dalam Perbankan Syariah di Indonesia, UII Press, Yogyakarta, 2017.

Mujahidin, Akhmad, Hukum Perbankan Syariah, Rajawali Press, 2016

Mardani, Hukum Bisnis Syariah, Kencana, Jakarta, 2014.

Pandam, Nurwulan dan Ina Faturohmah, "Akad Perbankan Syariah dan Penerapannya dalam Akta Notaris yang sesuai dengan Undang-Undang Jabatan Notaris", Penelitian Kolaborasi, Program Pasca Sarjana Fakultas Hukum Universitas Islam Indonesia, Yogyakarta, 2017.

Triyanta, Agus, Hukum Perbankan Syariah, Setara Press, Malang, 2016.

\section{Jurnal}

Deni, K Yusup “ Peran Notaris dalam Praktek Perjanjian Bisnis di Perbankan Syariah (Tinjauan dari Perpektif Hukum Ekonomi Syariah" dalam Al'ADALAH Volume XII. No 4, Desember 2015

Musjtari, Dewi Nurul, Rekonstruksi Lembaga Penyelesaian Sengketa Akad Pembiayaan Dengan Jaminan Hak Tanggungan Pasca Putusan Mahkamah Konstitusi Nomor 93/PUU-X/201, Media Hukum,Vol. 23 No. 1, 2016.

\section{Internet}

http:/ / pasca.unisba.ac.id/akad-murabahah-dan-implementasinya-pada-syariahdihubungkan-dengan-kebolehan-praktek-murabahah-menurut-paraulama/ diakses pada tanggal 09 Mei 2016 Pukul 10: 15 WIB

http:/ / notariat.fh.unsri.ac.id/userfiles/file/FEBRIYANTI\%20DWI\%20PUTRI\%20 02022681418036.pdf diakses pada 07 Desember 2017

http:/ /idr.iain-antasari.ac.id/178/, diakses pada 03 Februari 2018 


\section{Peraturan Perundang-undangan}

Undang-Undang Nomor 2 Tahun 2014 tentang Perubahan atas Undang-Undang Nomor 30 Tahun 2014 tentang Jabatan Notaris

Undang-Undang Nomor 30 Tahun 2014 tentang Jabatan Notaris

Undang-Undang Nomor 21 Tahun 2008 tentang Perbankan Syariah

Undang-Undang Nomor 4 Tahun 1996 tentang Hak Tanggungan Beserta BendaBenda yang berkaitan dengan Tanah 